\title{
In vitro haemostatic efficacy of aqueous, methanol and ethanol plant extracts of three medicinal plant species in Palestine
}

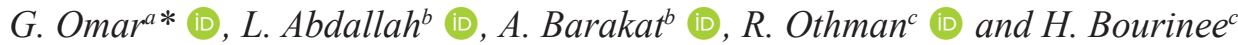 \\ aDepartment of Biology and Biotechnology, Faculty of Science, An-Najah National University, Nablus, Palestine \\ ${ }^{b}$ Department of Statistics, Faculty of Science, An-Najah National University, Nablus, Palestine \\ ${ }^{c}$ Department of Medical Laboratory Sciences, Faculty of Medicine and Health, An-Najah National University, \\ Nablus, Palestine \\ *e-mail: ghaderomar@najah.edu
}

Received: January 29, 2019 - Accepted: June 26, 2019 - Distributed: November 30, 2020

(With 2 figures)

\begin{abstract}
The haemostatic efficacy of different extract types of Satureja thymbra L., Thymbra spicata L. (Lamiaceae) and Verbascum fruticulosum Post. (Scrophulariaceae) was evaluated in this study via the Prothrombin time (PT) and Activated partial thromboplastin time (aPTT) analysis. Aqueous, methanol and ethanol extracts of the examined plant species leaves were prepared to a final concentration $50 \mathrm{mg} / \mathrm{mL}$. In vitro PT and aPTT assays were conducted on normal platelet poor plasma blood samples by a digital coagulation analyzer. The obtained results revealed anticoagulation activity of all investigated plant species with observed variations among them. The aqueous and ethanol extracts of T. spicata as well as the aqueous extract of $S$. thymbra prolonged PT values significantly $(\mathrm{p}<0.05)$. While, all $V$. fruticulosum extract types have had no significant effect on the PT values. The recorded aPTT data showed that all aqueous extracts have had a significant effect on the blood haemostasis as they increased aPTT values in all plant species under study. Out of which, both the ethanol and methanol extracts of T. spicata and methanol extract of S. thymbra showed similar effect. Of great concern, it was clearly noticed that the aqueous and ethanol extract of T. spicata and the aqueous extract of $S$. thymbra possess the strongest anticoagulation effect as they increased both PT and aPTT values significantly relative to the control $(\mathrm{p}<0.05)$. The variable anticoagulation bioactivity among the studied plant species could be referred to the various solvents degrees of solubility of different phyto-constituents. Thus, the efficacy of the plant species extracts evaluation as anticoagulants or coagulants were related to the plant species and to the solvent of extraction.
\end{abstract}

Keywords: medicinal plants, haemostasis, plant extract, Palestine.

\section{Eficácia hemostática in vitro de extratos aquosos, metanólicos e etanólicos de três espécies de plantas medicinais na Palestina}

\begin{abstract}
Resumo
A eficácia hemostática de diferentes tipos de extrato de Satureja thymbra L., Thymbra spicata L. (Lamiaceae) e Verbascum fruticulosum Post. (Scrophulariaceae) foi avaliada neste estudo pelo tempo de protrombina (TP) e tempo de tromboplastina parcial ativada (TTPa). Os extratos aquosos, metanólicos e etanólicos das folhas das espécies de plantas examinadas foram preparados para uma concentração final de $50 \mathrm{mg} / \mathrm{mL}$. Os ensaios de TP e TTPa in vitro foram realizados em amostras normais de sangue, pobre em plaquetas, por um analisador de coagulação digital. Os resultados obtidos revelaram atividade anticoagulante de todas as espécies de plantas investigadas, com variações observadas dentre elas. Os extratos aquosos e etanólicos de $T$. spicata e o extrato aquoso de $S$. thymbra prolongaram significativamente os valores de TP $(\mathrm{p}<0,05)$. Entretanto, todos os tipos de extratos de $V$. fruticulosum não tiveram efeito significativo sobre os valores de TP. Os dados registrados do TTPa mostraram que todos os extratos aquosos tiveram um efeito significativo na hemostase do sangue, pois aumentaram os valores de TTPa em todas as espécies de plantas em estudo. Dos quais, ambos os extratos etanólicos e metanólicos de T. spicata e o extrato metanólico de $S$. thymbra mostraram efeito semelhante. De grande preocupação, notou-se claramente que os extratos aquoso e etanólico de T. spicata e o extrato aquoso de $S$. thymbra apresentam efeito anticoagulante mais forte, aumentando os valores de TP e TTPa significativamente em relação ao controle $(\mathrm{p}<0,05)$. A variável bioatividade anticoagulante dentre as espécies vegetais estudadas pôde ser referida aos vários graus de solventes de solubilidade de diferentes fitoconstituintes. Assim, a eficácia da avaliação de extratos de espécies vegetais como anticoagulantes ou coagulantes foi relacionada às espécies vegetais e ao solvente de extração.
\end{abstract}

Palavras-chave: plantas medicinais, hemostase, extrato vegetal, Palestina.

Braz. J. Biol., 2020, vol. 80, no. 4 pp.763-768 


\section{Introduction}

Cardiovascular diseases are the leading cause of death in the world, that arise from the conflicts associated with blood coagulation (Rang et al., 2007; Buch et al., 2010). Coagulation cascade occurs either via the tissue factors (extrinsic pathway) or the contact factors (intrinsic pathway) (Palta et al., 2014). Increased coagulation is associated with several cardiovascular diseases including coronary heart disease and hypertension (Mekhfi et al., 2004). While decreased coagulation leads to prolonged bleeding time which results either from certain diseases like haemophilia or from drugs like aspirin (Vane and Botting, 2003).

Medicinal plants were and still used traditionally as protective natural medication (Sargin et al., 2015). Epidemiological and ethnomedical studies revealed that the risk of several diseases in general and cardiovascular ones in particular are reduced by a high consumption of medicinal plants (He et al., 2007; Sargin et al., 2015). The role of the plants bioactive compounds that provide this protection is a hot spot of research (He et al., 2007). For example, the flavonoids were proved that they demonstrate beneficial effects on cardiovascular risk factors including blood pressure, endothelial function, platelets function and cholesterolemia (Hooper et al., 2008). Also the salicylic acid which is another extracted phytochemical from Salix alba L., that is transformed into antiplatelet drug known by aspirin (Vane and Botting, 2003).

Since the concern towards the ethno-medicinal scientific justification, as well as, the over whiling seeking for remedies devoid for unfavorable side effects have prompted the fascination growth for natural haemostatic agent's discovery. Accordingly, novel coagulants or anticoagulants can be found in other plant species. On the other hand, folkloric haemostasis therapy use of some medicinal plants by herbalists is applied in several countries, one of which is Palestine. Therefore, previous studies were conducted to evaluate this issue. In 2014, Viscum album extracts from olive and almond host plants were proved to have significant prolongation effect on PT and aPTT (Abualhasan et al., 2014). Later on, another in vitro study showed that the ethanol extracts of Urtica urens, Parietaria judica, Satureja thymbra, Thymbra spicata, Teucrium creticum, Verbascum fruticulosum, Lupinus pilosus, Paronychia argentea, and Ruta chalepensis had either anticoagulation or coagulation effect on the examined blood samples (Omar et al., 2017). A wide spectrum of different phytochemicals could be extracted using various solvents due to variations in their solubility and polarity (Liu, 2003). As a result, the use of other extract types of the non-effective plant species, as well as the recorded effective ones may reveal different bioactivity on the different blood parameters. From this point of view, this research popped out to examine the haemostatic efficacy of different extract types of Satureja thymbra L., Thymbra spicata L. (Lamiaceae) and Verbascum fruticulosum Post. (Scrophulariaceae).

\section{Material and Methods}

\subsection{Plant materials}

The three plant species (Thymbra spicata L., Satureja thymbra L. and Verbascum fruticulosum Post) were collected and identified by Ghadeer Omar, Department of Biology \& Biotechnology, Faculty of Science, An-Najah National University; Palestine. Representative samples of the collected plant species under study were pressed till drying, treated chemically, mounted on herbarium sheets, provided with voucher numbers, and then they were deposited at An-Najah National University herbarium. The aerial parts of the plant materials were washed, air dried, ground into powder using grinder and stored at room temperature until they were used.

\subsection{Plant extraction procedure}

Ten grams of each plant powder were soaked in $100 \mathrm{~mL}$ sterile boiled distilled water for one week at room temperature with interval shaking. Then the mixtures were centrifuged for $5 \mathrm{~min}$ at $5000 \mathrm{rpm}$. The supernatants were evaporated by freeze-drying. The obtained powder of each of the plant species was dissolved in distilled water to a final concentration equal to $50 \mathrm{mg} / \mathrm{mL}$. However, for alcoholic extraction, ten grams of each plant powder were soaked in $100 \mathrm{~mL}$ of $(70 \%)$ ethanol or methanol for one week with interval shaking. Then the same steps of the aqueous extraction procedure were repeated, except that (1\%) dimethyl sulfoxide (DMSO) was used as a solvent and evaporation was performed by a rotary evaporator (Omar et al., 2017).

\subsection{Blood sample preparation}

Ten healthy volunteers were not under any medication and not smokers were asked to give blood samples. The citrated blood samples were prepared as the following; each blood sample was centrifuged at 3000 rpm for $15 \mathrm{~min}$ to obtain the Platelets Poor Plasma (PPP) (Saluja et al., 2011). All samples were subjected to PT and aPTT assays within 2 hours after blood collection. The clotting time for both tests was recorded by a digital coagulation analyzer (Coa DATA 4004, LAberBioMedical Technologies, Germany). All measurements were carried out in duplicates. The negative controls for PT and aPTT assays were distilled water for aqueous extract and $1 \%$ DMSO for alcoholic extracts.

\subsection{Prothrombin Time (PT) assay}

For in vitro PT assay, $50 \mu \mathrm{L}$ normal citrated PPP was incubated with $50 \mu \mathrm{L}$ from each plant extract for 5 min at $37^{\circ} \mathrm{C}$. Clotting time was immediately recorded after the addition of $100 \mu \mathrm{L}$ PT reagent (Hemostat thromboplastin-SI. Human, Germany).

\subsection{Activated Partial Thromboplastin Time (aPTT) assay}

For in vitro aPTT assay, $50 \mu \mathrm{L}$ normal citrated PPP was incubated with $50 \mu \mathrm{L}$ from each plant extract for $2 \mathrm{~min}$ at $37^{\circ} \mathrm{C}$. Then $50 \mu \mathrm{L}$ aPTT reagent (Human, Germany) was added and incubated for further $3 \mathrm{~min}$ at $37^{\circ} \mathrm{C}$. The aPTT 
clotting time was immediately recorded after the addition of $100 \mu \mathrm{L}$ calcium chloride solution (Human, Germany).

\subsection{Statistical analysis}

Statistical analysis of the PT and aPTT results was conducted using a statistical package SPSS via applying mean values using one-way ANOVA with post-hoc tests to determine if there was a significant difference among the different studied wild plant species extracts relative to the control. $\mathrm{P}$ value $<0.05$ was considered to be significant.

\section{Results and Discussion}

The examined blood samples were considered as representative samples for this study as no observed individual variations $(\mathrm{p}<0.01)$ in PT and aPTT data. Based on the obtained results, most of the studied plant extracts showed an effect on coagulation cascade by increasing PT or aPTT time or both (Table 1). The aqueous and ethanol extracts of T. spicata as well as the aqueous extract of S. thymbra prolonged PT values significantly $(\mathrm{p}<0.05)$. While, their other extract types and all $V$. fruticulosum extract types have had no significant effect on the PT values (Figure 1). The recorded aPTT data showed that all aqueous extracts had a significant effect on the blood haemostasis as they increased aPTT values in all plant species under study. Similarly, both the ethanol and methanol extracts of $T$. spicata and methanol extract of $S$. thymbra showed same effect (Figure 2). Of great concern, it was clearly noticed that the aqueous and ethanol extract of $T$. spicata and the aqueous extract of $S$. thymbra had the strongest anticoagulation effect as they increased both PT and aPTT values significantly relative to the control $(p<0.05)$.

The purpose of this study was to evaluate the haemostatic efficacy of different extract types of T. spicata, S. thymbra and $V$. fruticulosum leaves. The haemostatic effect was determined by PT and aPTT assays. The prothrombin time (PT) and activated partial thromboplastin time (aPTT) are indicators for coagulation since they are influenced by the susceptibility of the tissue factors (extrinsic) and contact factors (intrinsic) pathways, respectively (Palta et al., 2014). Standard clotting times for these two pathways are between 12.5 and $13.7 \mathrm{~s}$ for PT and between 31 and $39 \mathrm{~s}$ for aPTT (Lentner, 1984).
As the aqueous and ethanol extracts of $T$. spicata and the aqueous extract of $S$. thymbra prolonged both PT and aPTT values, they could be considered to have the strongest anticoagulation effect among other studied ones. This bioactivity could be referred to their act not only on the extrinsic (tissue factors) or intrinsic (contact factors) pathways, but also on the common one. On the other hand, the intrinsic (contact factors) pathway of the coagulation cascade was inhibited by the methanol extracts of T. spicata, and S. thymbra as well as the aqueous extract of $V$. fruticulosum by increasing only aPTT.

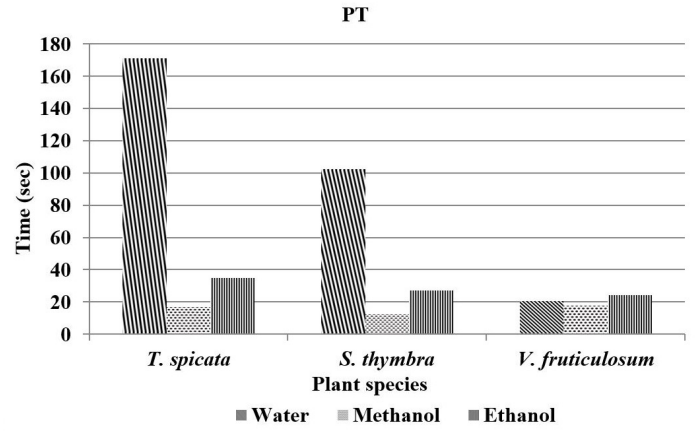

Figure 1. Prothrombin time (PT) values of the different examined plant species extracts types.

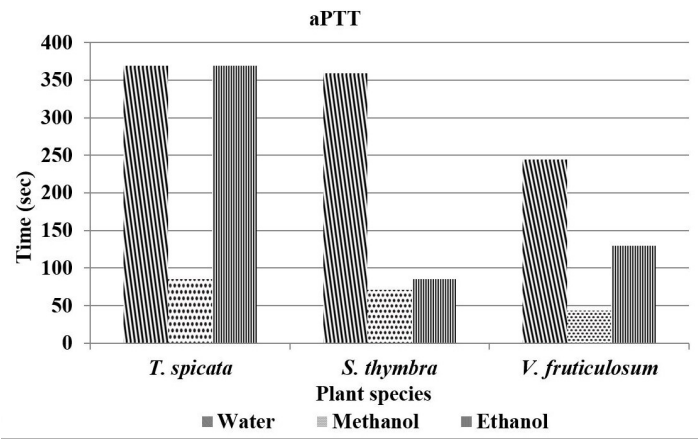

Figure 2. Activated partial thromboplastin time (aPTT) values of the different examined plant species extracts types.

Table 1. Prothrombin time (PT) and Activated partial thromboplastin time (aPTT) values of the studied plant species different extract types at $50 \mathrm{mg} / \mathrm{mL}$, illustrating the statistical $\mathrm{P}$ values.

\begin{tabular}{cccccc}
\hline Plant Species & Extract & PT (sec) & P value & aPTT (sec) & P value \\
\hline T. spicata & Water & 171.2 & 0.001 & 369.4 & 0.001 \\
& Methanol & 16.8 & 0.891 & 49.4 & 0.001 \\
S. thymbra & Ethanol & 35 & 0.002 & 369.5 & 0.001 \\
& Water & 102.4 & 0.001 & 359.2 & 0.001 \\
& Methanol & 12.4 & 0.999 & 70.8 & 0.001 \\
& Ethanol & 26.9 & 0.065 & 84.9 & 0.362 \\
& Water & 20.8 & 0.204 & 244.2 & 0.001 \\
& Methanol & 17.7 & 0.412 & 85.2 & 0.446 \\
\hline
\end{tabular}


Based on the obtained results, the decrease in the coagulation activity is mediated through the inhibition or decrease of the activity of several factors including tissue factors, thrombin, vitamin K-epoxide reductase and other clotting factors (Preusch and Smalley, 1990; Lee et al., 2004; Zhang et al., 2008). Therefore, the evaluation of those active plant extracts bioactivity mechanism on the coagulation cascade is required.

The essential oils extracted from $T$. spicata and $S$. thymbra leaves (and flowering tops) were estimated during the growing season leading to that the concentration of the phenolic constituent' scarvacrol and thymol were low in the early phenological stage and increased gradually with plant development. The changes in the essential oil content (quantity and composition) varied for the studied plant species, according to corresponding environmental and growth factors and the major adaptive strategy toward summer drought that each plant species has evolved. Taking this into account, the harvest of these two species in order to obtain their essential oils offers acceptable economic possibilities (Müller-Riebau et al., 1997). Similar results were obtained as revealed the presence of different phenolic compounds like thymol and carvacrol which belong to terpenoids in both plant species (Marković et al., 2011).

Also, flavonoids presence in Verbascum species in general were recorded (Riaz et al., 2013). While, the phytochemical screening of $V$. fruticulosum in particular showed that aqueous and acetone extracts contained flavonoids. Total phenol and flavonoid contents were highest in acetone extracts. While, the methanol extract showed the highest total tannin content. So all extracts except n-hexane contained phenol and tannins (Fares et al., 2018).

The presence of such phytochemicals in the plant species under study may explain their effect on the attenuation of the coagulation cascade. This out finding coincides with what have been recorded in literature. For example, a study on the effect of phenol and certain phenyl compounds on the different stages of the blood coagulation and fibrinolytic mechanism was investigated. Phenol has a complex action on blood coagulation. It produced a definite, though suboptimal platelet factor 3 activity, evolved factor XII, accelerated thrombin-fibrinogen interaction, retarded clot retraction, enhanced the action of streptokinase on plasminogen, and inhibited plasmin. In addition, the absence of factor XIII and calcium, it increased the solubility of fibrin in urea. Phenyl acetaldehyde, benzyl benzoate, and styrene (phenyl ethylene) accelerated clotting time and thrombin-fibrinogen reaction. Unpolymerized styrene and phenyl ethanol specifically inhibited the action of plasma thromboplastin, formed in a system lacking in factor VIII or IX. The contribution of platelets to plasma thromboplastin formation was examined in the light of these investigations, showing the ability of phosphorus-free compounds to supply a platelet-like activity (Nour-Eldin, 1968). In vitro platelets aggregation inhibition was referred to terpenoids which are phenols, explaining their extension tendencies to PT and aPPT (Cheng et al., 2014).
Moreover, since blood coagulation involves the generation of thrombin and conversion of fibrinogen into fibrin by active zymogens. This achieved via the activated factor X (FXa) which forms prothrombinase complex on phosphatidylserine containing surface by which prothrombin is converted to thrombin. One molecule of FXa generates more than 1000 thrombin molecules leading it to be a novel target for modern anticoagulant therapy. From this point of view the effects of the well-known plant polyphenolic compounds on factor Xa. Their results confirmed that only four polyphenols belonging to flavonoids group: procyanidin B2, cyanidin, quercetin and silybin, had inhibitory effect on FXa activity. This indicates that flavonoids might be potential structural bases for design of new nature-based, safe, orally bioavailable direct FXa inhibitors (Bijak et al., 2014). Moreover, the flavonoids and tannins proved their effect on the PT and aPPT (Adli et al., 2016), which went along with a haemostatic mechanism in vivo study that previously proved falvonoids effect on the coagulation cascade (Tanko et al., 2012).

Furthermore, the plants are known with their carbohydrates and proteins contents which were recorded to have bioactivity on the blood haemostasis. For example, polysaccharides such as pectins and hemicelluloses that were isolated from different plant species demonstrated antithrombin and thrombolytic activity (Mengome et al., 2014). Similarly, plant lectins affect blood haemostasis by increasing both PT and APTT (Luz et al., 2013). In addition, cysteine proteases which are extracted from several plants latex exhibit fibrinolytic activity and reduce clotting time in a concentration dependent manner (Rajesh et al., 2007; Shivaprasad et al., 2009; Ramos et al., 2013).

As a result, plant extracts contain variable constituents which show different haemostatic bioactivity based on the type of extraction of a particular plant species. Therefore, this fact is confirmed by that the bioactivities of different plant species can be attributed to a synergic action among the molecules (Silva et al., 2009). So, the efficacy of the plant species extracts evaluation as anticoagulants or coagulants were related to various degree of solubility of different molecules. Nevertheless, the variability in the constitution of essential oils is also directly related to the species, and, within the same species. Since several factors can affect their composition, such as chemotype, location, collection period, and vegetative cycle (Gobbo-Neto and Lopes, 2007).

In conclusion, the positive recorded data would serve as a source of a novel, effective haemostatic agents that improve the management of cardiovascular diseases. In spite of that, further phytochemical studies for the purification and characterization of the active ingredients of the examined plant species extracts are still recommended.

\section{Acknowledgements}

We would like to thanks Biology and Biotechnology Department at An-Najah National University for allowing us to access their facilities. 


\section{References}

ABUALHASAN, M., JARADAT, N., ABU-HASAN, N., ALMASRI, M., ABU TAHA, A., RABBAA, A., NATSHEH, N., SHALALFEH, S. and NAJIB, M., 2014. Bioactivity of Viscum album extracts from olive and almond host plants in Palestine. Pharmacognosy Journal, vol. 6, no. 2, pp. 117-123. http://dx.doi. org/10.5530/pj.2014.2.7.

ADLI, N., ABU, M.N., MASTUKI, M.F., WAN YUSOFF, W.S.Y. and KAMARUDIN, E., 2016. In vitro haemostatic activity of rhodomyrtus tomentosa (Aiton) hassk. Aqueous leaf extract. Jurnal Teknologi, vol. 78, no. 5-6, pp. 15-19. http://dx.doi. org/10.11113/jt.v78.8632.

BIJAK, M., PONCZEK, M.B. and NOWAK, P., 2014. Polyphenol compounds belonging to flavonoids inhibit activity of coagulation factor X. International Journal of Biological Macromolecules, vol. 65, pp. 129-135. http://dx.doi.org/10.1016/j.ijbiomac.2014.01.023. PMid:24444877.

BUCH, M.H., PRENDERGAST, B.D. and STOREY, R.F., 2010. Antiplatelet therapy and vascular disease: an update. Therapeutic Advances in Cardiovascular Disease, vol. 4, no. 4, pp. 249-275. http://dx.doi.org/10.1177/1753944710375780. PMid:21303843.

CHENG, P., LIANG, X., XIAOFANG, X., QINMEI, Z., LI, G. and ZHAOHUA, L., 2014. Application of terpenoid. U.S. Patent No. CN103211809A. Washington: U.S. Patent and Trademark Office.

FARES, S.S.F., ALKOWNI, R. and JARADAT, N., 2018. Antimicrobial activities and phytochemical analysis of Verbascum fruticulosum. Nablus, Palestine: Faculty of Graduate Studies, An-Najah National University. Master thesis.

GOBBO-NETO, L. and LOPES, N.P., 2007. Medicinal plants: factors of influence on the content of secondary metabolites. Química Nova, vol. 30, no. 2, pp. 374-381. http://dx.doi.org/10.1590/ S0100-40422007000200026.

HE, F.J., NOWSON, C.A., LUCAS, M. and MACGREGOR, G.A., 2007. Increased consumption of fruit and vegetables is related to a reduced risk of coronary heart disease: meta-analysis of cohort studies. Journal of Human Hypertension, vol. 21, no. 9, pp. 717728. http://dx.doi.org/10.1038/sj.jhh.1002212. PMid:17443205.

HOOPER, L., KROON, P.A., RIMM, E.B., COHN, J.S., HARVEY, I., LE CORNU, K.A., RYDER, J.J., HALL, W.L. and CASSIDY, A., 2008. Flavonoids, flavonoid-rich foods, and cardiovascular risk: a meta-analysis of randomized controlled trials. The American Journal of Clinical Nutrition, vol. 88, no. 1, pp. 38-50. http://dx.doi.org/10.1093/ajcn/88.1.38. PMid:18614722.

LEE, M.H., SON, Y.K. and HAN, Y.N., 2004. Tissue factor inhibitory sesquiterpene glycoside from Eriobotrya japonica. Archives of Pharmacal Research, vol. 27, no. 6, pp. 619-623. http://dx.doi.org/10.1007/BF02980160. PMid:15283463.

LENTNER, C., 1984. Physical chemistry, composition of the blood, hematology, somatometric data. Basel: Ciba Geigy. Geigy Scientific Tables, vol. 3 .

LIU, R.H., 2003. Health benefits of fruit and vegetables are from additive and synergistic combinations of phytochemicals. The American Journal of Clinical Nutrition, vol. 78, no. 3, suppl., pp. 517S-520S. http://dx.doi.org/10.1093/ajcn/78.3.517S. PMid:12936943.

LUZ, L.A., SILVA, M.C., FERREIRA, R.S., SANTANA, L.A., SILVA-LUCCA, R.A., MENTELE, R., OLIVA, M.L., PAIVA,
P.M. and COELHO, L.C., 2013. Structural characterization of coagulant Moringa oleifera Lectin and its effect on hemostatic parameters. International Journal of Biological Macromolecules, vol. 58, pp. 31-36. http://dx.doi.org/10.1016/j.ijbiomac.2013.03.044. PMid:23537800.

MARKOVIĆ, T., CHATZOPOULOU, P., ŠILJEGOVIĆ, J., NIKOLIĆ, M., GLAMOČLIJA, J., CIRIC, A. and SOKOVIC, M., 2011. Chemical analysis and antimicrobial activities of the essential oils of Satureja thymbra L. and Thymbra spicata L. and their main components. Archives of Biological Sciences, vol. 63, no. 2, pp. 457-464. http://dx.doi.org/10.2298/ABS1102457M.

MEKHFI, H., EL HAOUARI, M., LEGSSYER, A., BNOUHAM, M., AZIZ, M., ATMANI, F., REMMAL, A. and ZIYYAT, A., 2004. Platelet anti-aggregant property of some Moroccan medicinal plants. Journal of Ethnopharmacology, vol. 94, no. 2-3, pp. 317-322. http://dx.doi.org/10.1016/j.jep.2004.06.005. PMid:15325737.

MENGOME, L.E., VOXEUR, A., AKUE, J.P., LEROUGE, P., NGOUAMIZOKOU, A. and MOUTSIMBI, R.M., 2014. Analysis of toxicity and hemostatic properties of polysaccharides from plants endemic to Gabon. British Journal of Pharmacology and Toxicology, vol. 5, no. 6, pp. 186-193. http://dx.doi.org/10.19026/ bjpt.5.5185.

MÜLLER-RIEBAU, F.J., BERGER, B.M., YEGEN, O. and CAKIR, C., 1997. Seasonal Variations in the Chemical compositions of essential oils of selected aromatic plants growing wild in Turkey. Journal of Agricultural and Food Chemistry, vol. 45, no. 12, pp. 4821-4825. http://dx.doi.org/10.1021/jf970110y.

NOUR-ELDIN, F., 1968. Phenols and blood coagulation. Journal of Biomedical Materials Research Banner, vol. 2, no. 1, pp. 2342. http://dx.doi.org/10.1002/jbm.820020103.

OMAR, G., ABDALLAH, L., RAHIM, A., OTHMAN, R. and BARAKAT, A., 2017. Selected wild plants ethanol extracts bioactivity on the coagulation cascade. Journal of Scientific Research and Reports, vol. 13, no. 6, pp. 1-10. http://dx.doi. org/10.9734/JSRR/2017/32989.

PALTA, S., SAROA, R. and PALTA, A., 2014. Overview of the coagulation system. Indian Journal of Anaesthesia, vol. 58, no. 5, pp. 515-523. http://dx.doi.org/10.4103/0019-5049.144643. PMid:25535411

PREUSCH, P.C. and SMALLEY, D.M., 1990. Vitamin K1 2,3-epoxide and quinine reduction: mechanism and inhibition. Free Radical Research Communications, vol. 8, no. 4-6, pp. 401-415. http://dx.doi.org/10.3109/10715769009053374. PMid:2113031.

RAJESH, R., SHIVAPRASAD, H.V., GOWDA, C.D., NATARAJU, A., DHANANJAYA, B.L. and VISHWANATH, B.S., 2007. Comparative study on plant latex proteases and their involvement in hemostasis: a special emphasis on clot inducing and dissolving properties. Planta Medica, vol. 73, no. 10, pp. 1061-1067. http:// dx.doi.org/10.1055/s-2007-981575. PMid:17691056.

RAMOS, M.V., ARAÚJO, E.S., JUCÁ, T.L., MONTEIROMOREIRA, A.C., VASCONCELOS, I.M., MOREIRA, R.A., VIANA, C.A., BELTRAMINI, L.M., PEREIRA, D.A. and MORENO, F.B., 2013. New insights into the complex mixture of latex cysteine peptidases in Calotropis procera. International Journal of Biological Macromolecules, vol. 58, pp. 211-219. http:// dx.doi.org/10.1016/j.ijbiomac.2013.04.001. PMid:23583491.

RANG, H.P., DALE, M.M., RITTER, J.M. and FLOWER, R.J., 2007. Rang and Dale's pharmacology. London: Churchill Livingstone, pp. 332-345. 
RIAZ, M., ZIA-UL-HAQ, M. and JAAFAR, H.Z.E., 2013. Common mullein, pharmacological and chemical aspects. Revista Brasileira de Farmacognosia, vol. 23, no. 6, pp. 948-959. http:// dx.doi.org/10.1590/S0102-695X2013000600012.

SALUJA, H., DEHANE, V. and MAHINDRA, U., 2011. Platelet-Rich fibrin: a second generation platelet concentrate and a new friend of oral and maxillofacial surgeons. Annals of Maxillofacial Surgery, vol. 1, no. 1, pp. 53-57. http://dx.doi. org/10.4103/2231-0746.83158. PMid:23482459.

SARGIN, S.A., SELVI, S. and BÜYÜKCENGIZ, M., 2015. Ethnomedicinal plants of Aydıncık District of Mersin, Turkey. Journal of Ethnopharmacology, vol. 174, pp. 200-216. http:// dx.doi.org/10.1016/j.jep.2015.08.008. PMid:26278812.

SHIVAPRASAD, H.V., RIYAZ, M., VENKATESH KUMAR, R., DHARMAPPA, K.K., TARANNUM, S., SIDDESHA, J.M., RAJESH, R. and VISHWANATH, B.S., 2009. Cysteine proteases from the Asclepiadaceae plants latex exhibited thrombin and plasmin like activities. Journal of Thrombosis and Thrombolysis, vol. 28, no. 3, pp. 304-308. http://dx.doi.org/10.1007/s11239-0080290-2. PMid:18979066.
SILVA, C.B., SIMIONATTO, E., HESS, S.C., PERES, M.T.L.P., SIMIONATTO, E.L., WISNIEWSKI JÚNIOR, A., POPPI, N.R., FACCENDA, O., CÂNDIDO, A.C.S. and SCALON, S.P.Q., 2009. Chemical composition and allelophatic activity of essential oil from Hydrocotyle bonariensis Lam (araliaceae). Química Nova, vol. 32, no. 9, pp. 2373-2376.

TANKO, Y., EZE, E.D., JIMOH, A., YUSOF, K., MOHAMMED, K.A., BALARABE, F. and MOHAMMED, A., 2012. Haemostatic effect of aqueous extract of mushroom (Ganoderma lucidum). Pelagia Research Library, vol. 2, no. 6, pp. 2015-2018.

VANE, J.R. and BOTTING, R.M., 2003. The mechanism of action of aspirin. Thrombosis Research, vol. 110, no. 5-6, pp. 255-258. http://dx.doi.org/10.1016/S0049-3848(03)00379-7. PMid:14592543.

ZHANG, S., YIN, T., LING, X., LIANG, H. and ZHAO, Y., 2008. Interactions between thrombin and natural products of Millettia speciosa Champ. Using capillary zone electrophoresis. Electrophoresis, vol. 29, no. 16, pp. 3391-3397. http://dx.doi. org/10.1002/elps.200800174. PMid:18633944. 